\title{
Muslimness Discourse, Religious Authority, and Cyber-Media Activism in Contemporary Indonesia
}

\author{
A K Kurniawan' ${ }^{1}$, F F Alhaq ${ }^{2}$ \\ The Faculty of Ushuluddin and Adab, UIN Sultan Maulana Hasanuddin Banten, Indonesia ${ }^{1}$ \\ The Faculty of Shari'a, UIN Sultan Maulana Hasanuddin Banten ${ }^{2}$ \\ \{ade.fakih@uinbanten.ac.id ${ }^{1}$, falikhalhaq50@gmail.com²
}

\begin{abstract}
This paper focuses on the phenomena of Indonesian Muslim's cyber-media activism dealing with Muslimness persuasive message and piety, discourse, and the shifting of religious authority. The expression of Islam in the Indonesian public sphere, in the last decade, is interesting to be observed. It is not only because of getting world special attention dealing with the issue of religious violence, extremism, and terrorism but also having a number of increasing cultural Islam, particularly expressing Muslimness identity in the public sphere and articulating piety in the sense of Indonesia's democracy. The hardening of religious identity in current Indonesia's political circumstance is inseparable with the historical trajectory of Muslimness persuasive message through cyber-media activism as its pre-condition. Drawing on Fairclough's Critical Discourse Analysis (CDA), this paper analyzes also religious discourse and the shifting of religious authority as an impact of those movements. In supporting data, I utilize both bibliographical and empirical investigation.
\end{abstract}

Keywords: Cyber-Media, Muslimness, Piety, Discourse, Authority.

\section{Introduction}

After the downfall of Soeharto's New Order regime in 1998, Indonesia has experienced the euphoria of freedom of speech and democracy. This condition provides fresh air for the emergence of many social and religious movements to express their symbols in Indonesia's public space. The emergence of these movements not only shows the diversity of groups and movements but also raises actors and new agendas that foreshadowed Indonesia's political system and culture.

In the condition of which Indonesia experiences modernization and globalization, Islam becomes publicly visible and symbolically actualized. Some scholars consider that the growth of Islam in the public sphere is one of the most extraordinary developments taking place in this country[1]. The religious awareness of Indonesian Muslim communities and their desire to demonstrate personal piety in the public sphere has made Islam moves increasingly to the center and becomes part of political expression, legal transactions, economic activities, and socio-cultural practices. The development of Islamic influence in the public sphere is in line with the emphasis on Islamic symbols, the proliferation of Islamic institutions, and new lifestyles, especially among the middleclass Muslim [2, p. 1]. The phenomenon of the hijab syar'i, hijrah, until NKRI Bersyari'ah becomes a new precipitate of the expression of some Indonesian Muslim communities towards Muslimness identity.Symbolic expressions of Islam are also increasingly read and seen on the Internet that makes Islam as part of the virtual religion. Simply word, in a democratic state's public sphere, the penetration of Islamic symbols widely and deeply delivers Islamic expressions, identities, organizations, and institutions in various forms.

Media, especially virtual media, is the most effective and massive means for Islamic proliferation. Today, we can find Da'wah in various forms. Not only conventional da'wah through preaching, the proliferation of Islamic values is also carried out through modern devices such as cyber proselytization, cellular da'wah, instant religious messages via SMS and web-based services, and the most influential today is social media such as Youtube, Facebook, Twitter, Instagram, and others all of which bring Islam personally in daily life and can be accessed directly.

The proliferation of Islamic identity involves many young people in the discourse. The involvement of youth contributes tothe real influence on Islamic activism in Indonesia. The amalgamation between the potential of youth spirit, adaptation to modernism and globalism, and the social media spread the power of the Islamic 
activism makes this movement to have innovations and cultural negotiation in a variety of colors and shapes in demonstrating symbols of piety and wider collective identity, although sometimes it ignites polemics and provokes friction between Islamic groups.

Beyond its political expression, these Islamic symbols exert a significant influence in shaping a Muslim's new pious identity in the public sphere through cultural symbols: hijab syar'i, soap operas, cinemas, banners, Islamic books, and broadcasting Islamic messages on social media. In a study conducted by CSRC UIN Jakarta, it was stated that the massive dissemination of Islamic symbols in the democratic public sphere in Indonesia had a paradoxical impression. Furthermore, the results of CSRC research show speculation that the spread of these symbols, though sometimes exclusive, will give a positive signal rather than as a threat to democracy and the future of pluralism in Indonesia. The CSRC researchers believe that $80.1 \%$ of Indonesian people tend to be moderate, cultural, pluralist, and able to adapt to modern social and economic dynamics. Although, they also did not dismiss the existence of Islamist-ideological-radical circles who continue to undermine the democratic system in this country[3].

In the same optimistic tone, Noorhaidi stated that in some respects the strengthening of Islamic identity and the penetration of modernism were also able to make religious rituals negotiate culturally and even adapt to the political conditions that were taking place [2]. Even so, he also highlighted the role of young people who have a very important role in strengthening Islamic identity amid modernism. According to him, globalism has brought the spirit of Islamic revivalism in Indonesia and is consumed significantly among young people. Even so, the identity and symbols of Islam can adapt to the style and spirit of young people, which later led to the term "cool Islam" which is trendy and fashionable [2].

In contrast to Noorhaidi, Pamungkas and Oktaviani in their collaborated writing said that the deposition of Islamic identity that had been cultivated for a long time was able to settle into a political force capable of influencing domestic political constellation. He cited the Aksi Bela Islam(Defending Islam Action) which was able to reduce Ahok (Basuki Tjahaya Purnama) from his power for alleged blasphemy. According to them, the shifting narrative about Islam is possible because it is supported by new media that can influence the cultural and political landscape of everyday Muslim life. The Ahok case is a reflection that the organizers of the Defending Islam Action were able to mobilize mass support through campaigns on social media [4].

Furthermore, Ahyar and Alfitri analyzed the Defending Islam Action movement which is often claimed as the victory of Islamic activism. In their collaborated writing, they try to analyze the discourse of Islamic activism in the online public sphere that is exploring the internet and online social media as a new medium of the transformation of religious authority propaganda from traditional to modern among millennials, who are technologically literate [5].

Unlike researchers above, the focus of this paper is not only to deal with the role of social media and the Muslim activism but also to analyze how the religious symbols, slowly but surely, shape the new Muslimness identity which later becomes a force to gather real political support. While the latter two works only focus on one of the movements - the Action of Defending Islam - which use social media as a means of mobilizing mass support, and how online media influences mass movements in the real world (offline), this paper actually explores further on minor discourses in the media social but greatly influences the reception of Muslim communities about the propaganda of Islamic values.

\section{Method}

The study in this paper was carried out through two methods. First, through observation on social media and discourse analysis in interpreting forms of representation of Islamic symbols, Muslimness identity, and discourse that appear on social media networks. Second, through visual ethnographic and field observations to see the phenomenon of the spread of Islamic symbols and the strengthening of Muslimness identity and its implications in real social and political movements, such as the Defending Islam Action and hijrah movement.

Through visual observation of the phenomenon of the spreading Islamic symbols and the strengthening of Muslimness identities on social media. Whereas ethnographic observations within Muslim communities, especially in the polemic discourse of Muslimness identity, are intended to show how 'Muslim public space' is managed in community bases which even at the beginning of history had no political interest in the Offline Social Movement, such as the Defending Islam Action (which was originally intended as a political interest to imprison Ahok). Through an ethnographic study of the phenomenon of spreading Islamic symbols and discourse on Muslimness identity, it can be recognized how the messages of Islamic values that were initially spread 
massively without any tendency to carry out political movements can be used by certain parties as an attraction for mass support of political action.

\section{Result and Discussion}

\section{Cyber-Media Activism and Shaping Muslimness Identity}

The fact that Islam becomes more publicly visible is one of the most remarkable developments that currently occurs in the country [6], [7]. Salvatore and Eickelman observe the appearance of so-called "public Islam" in the Muslim world, an "Islamic" public sphere which enables a large segment of diverse Muslims to make their voices heard in civic debate and public life, adapts itself with modern circumstances and distinctively opens senses of political and religious identity[8].

The contestation of Islamic identity in the social media shows at least two different ways of addressing culture and traditions that exist in Indonesia today. First, we often find that some Islamic groups loudly and convincingly criticize, attack, and even prescribe existing local traditions, cultures, as well as other group's religious orientations. An encounter of some Islamic activisms occurs in numerous ways. To mention some of them, for example, are intensive counter-campaign to celebrate the new year along with the blowing of trumpets as Western party is prohibited (haram) and alleged as an imitation of the pagan tradition, as well as the celebration of Valentine's Day, playing several musical instruments, Sufi healing (so that they offer ruqyahsyar'iyyah), and prohibition mauled tradition. They deem those practices as 'innovation' (bid'a).

Second, another Islamic activism is more accommodative in addressing the existing cultures and traditions in the midst of society. On the pretext that Islam as a mercy in the universe and that Islam is a way of life, they did not hesitate to apply Islamic values with the devices and modern culture. The group is also varied, to call them are One Day One Juz (ODOJ) activism which currently has thousands of members. There is also a movement of young people in Bandung, namely "Gerakan Pemuda Hijrah" (Hijrah Youth Movement) founded by Hannan Attaki, which campaigns for the youth to close and friendly to the mosque with the solicitation language and distinctive appearance youth jocks and stylish.

Today, hijrah is a phenomenon that has been accepted massively by many millennials and Muslim middle classes. Muslims who are involved in this 'hijrah' movement can be easily observed in the public sphere which is marked by changes in dress code. They, from those who were only wearing tight clothes for women, have now changed in whole-closed clothing that extends throughout their bodies and using the niqab. Whereas for men are usually marked with typical Middle Eastern clothing or wearing pants whose length does not exceed the ankles (anti-Isybal), letting the beard grow, sometimes blackening the forehead. In addition to fashion, transformation changes also occur in the use of language. For example, they previously used the word "saya/kita (you/we)" to "ana/antum", from the word "iya (yes)" to "na'am"; from "otw (on the way)" to "bmw (Bismillahi Majreha Wamursaha)". Some even changed their names, for instance from Suryadi to Abu Yusuf al-Battawi, from what was previously called Maryati to Ummu Salamah. They recognize that these changes are part of the attempt to be hijrah o to be Muslim Kaffah, i.e. moving from what is 'un-Islamic' to the 'Islamic' one.

The broadcast of massive Islamic messages carried out continuously on social media sets a precedent that gives a lot of influence to the new meaning of Muslimness identity in the public sphere. Islamic persuasive messages spread through online media, such as Twitter, YouTube, WhatsApp, and memes, and offline media, such as banner and billboardwhich can influence the acceptance of new Muslim identities and then attract their support to be involved in, for example, the hijrah movement. Many young people are interested in joining this movement after receiving a lot of Islamic messages on social media. Rahma (24), for example, when interviewed about her decision to involve in hijrah movement said that her choice to dohijrah was her personal decision after several months of pondering the posting of Islamic messages that she got from several WhatsApp groups and watching the preaching of Ust Hanan Attaki, Ust. Adi Hidayat, Ust. Abdul Somad, and Ust. Khalid Basalamah on the Youtube channel. This decision became even stronger when she joined a religious studyclub (majlis pengajian) that almost all of his congregation had decided to do hijrah. ${ }^{1}$ The same thing was conveyed by Zahra (26), ${ }^{2}$ Firda (19), ${ }^{3}$ Ummu Salamah (28), ${ }^{4}$ Hafid (29), ${ }^{5}$ and Marwan (25), ${ }^{6}$ of course with a variety of reasons that

\footnotetext{
${ }^{1}$ Interview with Rahma (female, 24 years old) in Serang, Banten, on 22 July 2019

${ }^{2}$ Interview with Zahra (female, 26 years old) in Serang, Banten, on 22 July 2019

${ }^{3}$ Interview with Firda (female, 19 years old) in South Jakarta on 5 August 2019

${ }^{4}$ Interview with Ummu Salamah (female, 28 years old) in South Jakarta on 5 August 2019

${ }^{5}$ Interview with Hafid (male, 29 years old) in Serang, Banten, on 29 July 2019

${ }^{6}$ Interview with Marwan (male, 25 years old) in Serang, Banten, on 29 July 2019
} 
are slightly different from one another. Although their reasons vary, there are similarities that encourage them to do hijrah, namely the influence of Social Media.

The existence of young people, in this case, is not only as consumers who receive the distribution of Islamic messages on social media but also as producers, which they themselves refer to as "agen kebaikan" (agents of goodness). As Hafid (29)said that young people have the ability to absorb well the Islamic values conveyed in the teachings, both offline and online Islamic preaching by Ustadh, and also through the broadcast of Islamic persuasive messages on social media. In addition, they also become agents of kindness for the people, at least if they have not been able to convey the preaching of Islam ( $d a^{\prime}$ wah) they can broadcast the Islamic messages received from ustadhto the public through social media as a simple reminder each other of Islamic goodness values. $^{7}$ It is this second role that turns out to have a lot of influence, especially in establishing a new model of Muslimness identity in society. In doing so, these militant netizens are able to package Islamic content very well with illustrations and adaptations of youthful characters.

The public sphere media is generally placed in a strategic location and in social media, so it can be accessed massively by the community. The content of public sphere media is quite diverse, but the most common is the invitation to perform zakatand sodaqoh, economic Sharia, avoiding riba, the feature of Islam and the Sharia as a solution to the current crisis, youth issues in the perspective of Islam, as well as the Islamic propaganda which often attack other groups with different religious orientation or other religions. These themes are generally voiced by Islamists. According to research conducted by the CSRC, statistically, laying symbol teachings and Islamic propaganda in the public sphere is a very high impact for Muslim society.[3]

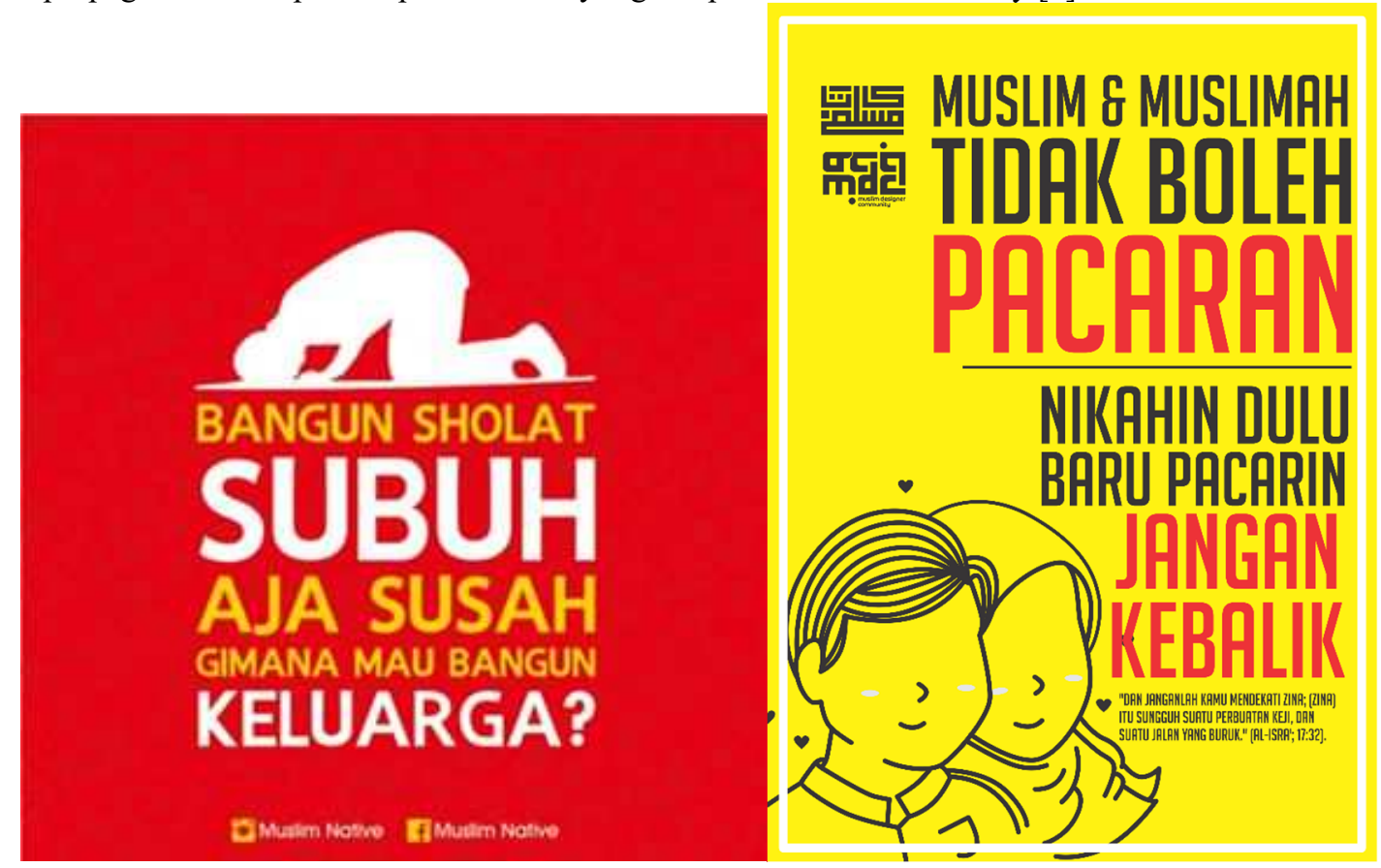

The reality of the diversity of religious expression brings its own problems. It does not only involve the issue of public space that often faces high tension, but also the possibility of contestation or negotiation between religious groups of different political and ideological orientations. Although all Muslim groups make Islam their theological foundation, they differ on how Islam should be interpreted and how political relations should be built. On the one hand, there are several groups who claim Islam as the basis of political life, while recognizing the context of religious plurality. On the other hand, some reject the ideology of political Islam and decide to make Islam as a cultural identity which is intertwined and aligned with other identities, such as economic status, social grouping, and national identity.

\section{Media Framing, Discourse, and Shifting Religious Authority}

Using the Internet as propaganda has a massive influence among people. Besides being easily accessible by anyone, anywhere, and anytime, online media provides information services with a variety of perspectives,

\footnotetext{
${ }^{7}$ Interview with Hafid (male, 29 years old) in Serang, Banten, on 29 July 2019
} 
including religious issues. For Islamists, using the Internet to make propaganda and to identify themselves or to differentiate the other is one of the effective strategies to achieve their ideological objectives. They realize that the current online media is one of the important means in the process of understanding religion in modern society. They create stylish websites to provide information, knowledge, debate on the latest issues of theology and more specifically a particular ideology.

An example of a short message in the form of texts, memes, stickers or posters that attacking one another is a Sunni-Shiite discourse on the public media. The sectarian propaganda thrives in social media and shapes public discourse. Because of the range of social media or "cyberspace" is broader than the "real space", then its effect becomes wider in the public. Indeed, those who are involved in the discussion did not grasp the constellation of political and ideological progress. This is the power of social media to forms the minds of those who saw him and lead the discourse as if what they see is a mirror of reality.
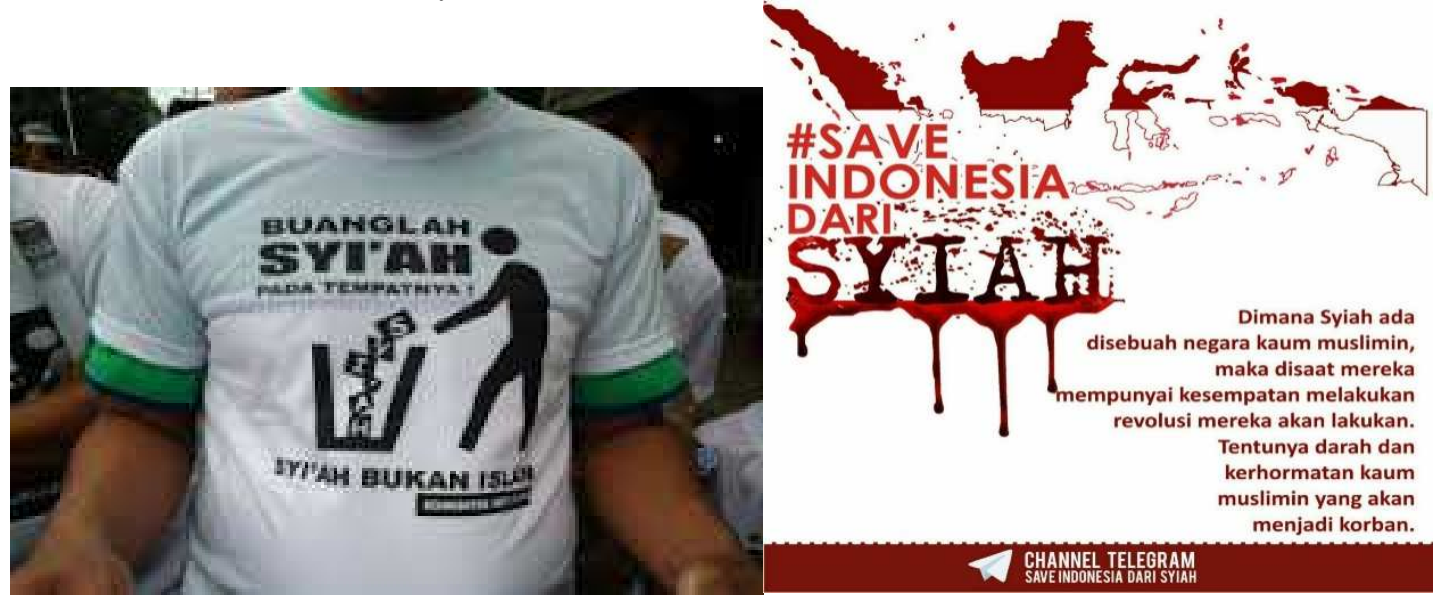

This propaganda gets some reactions, which do not only come from Shia followers but also from others who feel being disturbed by Wahabi-Salafi's propaganda that took place in Indonesia as their ideological battlefield.

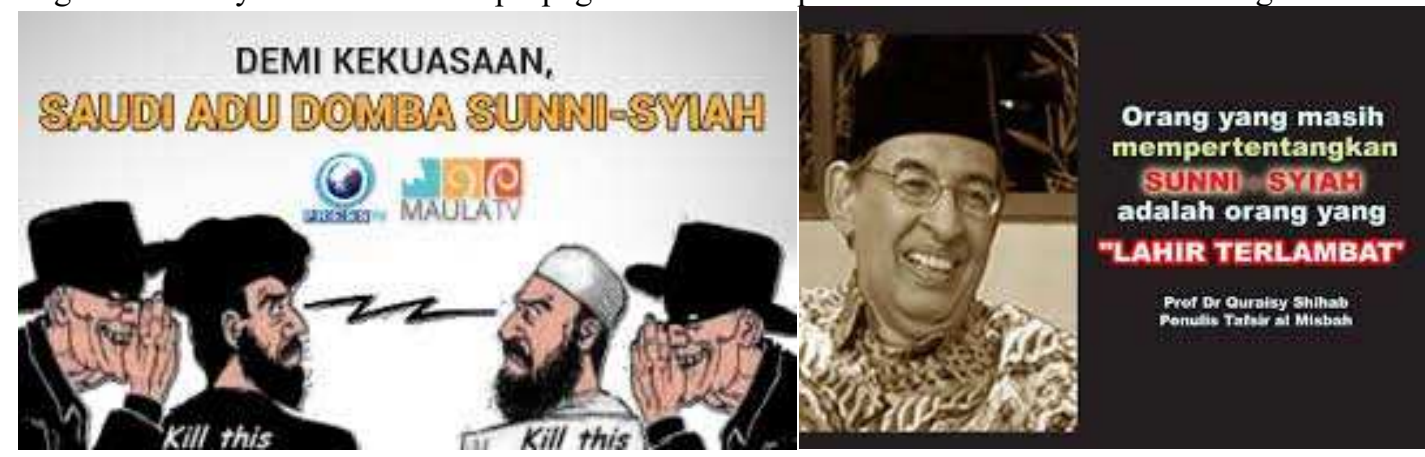

In another side, some people also criticize Wahabis or Salafis' literalistic way on their religious understanding in daily life. 


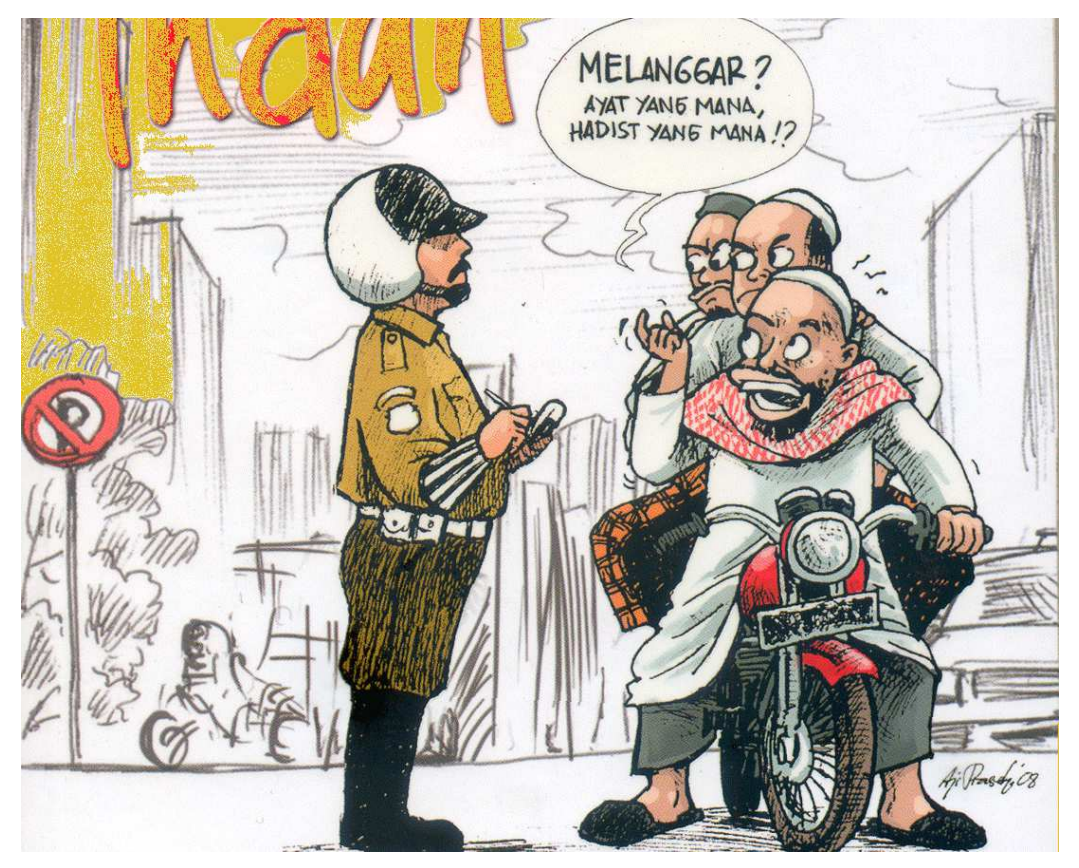

Another phenomenon which became a heated discussion on social media and continued to become a real mass action in the national to international scale is the case of Basuki Tjahaya Purnama (a.k.a. Ahok). The statement of this former Jakarta governor triggered mass protests in the name of "defending Islam" in Indonesia. The action began at the end of 2016 and continued until 2018 due to Ahok's speech during a working visit of socialization of the provincial government program to Pramuka Island in the Thousand Islands Jakarta on September 27, 2016. The speech became a heated discussion immediately after Buni Yani, a Youtuber, uploaded a speech video with additional uploader comments that said that the video had insulted the Quran [9, pp. 17-18]. This short video was then distributed by hundreds of netizens on various social media or online short messages such as Facebook, Twitter, Instagram, WhatsApp, and Line. This video then succeeded in triggering anger among the Muslim community with various forms of anger posts: whether in the form of pictures, photos, statuses, or brief comments on various social media platforms. Although it also provoked the reaction of several parties to defend Ahok. Even so, it did not dampen some Muslim circles to conduct a series of demonstrations following the post-distribution of Ahok's video [10, pp. 62-65]. In mid-October 2016, a group of people gathered in front of the Jakarta city hall to protest Ahok's statement of insulting Muslims. Demonstrations continued on 4 November 2016, 2 December 2016, 21 February 2017, 3 March 2017, and 5 May 2017 with greater mass.

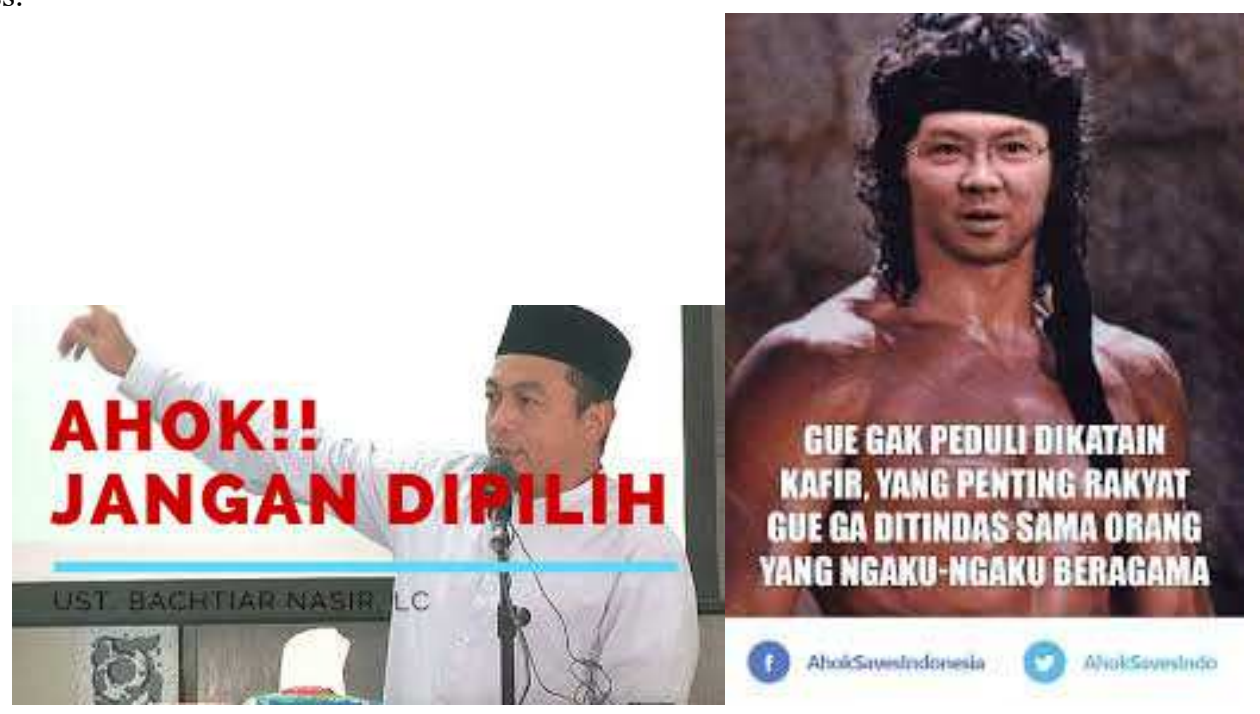


Looking at the composition of the involvement of mass organizations in the Ahok case, power relations that take place in the online space with all its construction also affect the dynamics that occur in the offline space. The online space provides online news site opportunities to provide public participation. The comments room becomes an opportunity for the public to participate in discourse that occurs both in the offline and online space. The virtual space gives freedom to the public to claim the space of interpretation of reality that takes place in the offline space, as well as criticism of certain groups.

Facebook became the starting point for the broadcasting news related to blasphemy by Basuki Tjahaja Purnama (Ahok) that was initially spread through the Facebook account of Buni Yani on October 6, 2016. A total of 346,354 impressions of the spread of discourse and 11,033 times were re-shared. Video as one of the productions of knowledge enhanced with an additional caption to the curiosity of increased social media viewers. The video uploaded with 346,364 impressions, 3.8 thousand emoticons, and 11,033 comments were the trigger of the Action of Defending Islam II (411) and III (212)[4].

The success in mobilizing mass support in the Defending Islam Action was also carried out with the media framing: 'romanticizing' the lives of 'marginalized santri' who were willing to sacrifice anything to defend their 'dignity of the Islamic faith'. This was the spotlight on the news in the leading mass media in Indonesia, which had previously been mobilized by sympathizers and cadres of GNPF-MUI through social media. For example, media framing of the 'Walk Action of Santri from Ciamis' to Jakarta to support the Defending Islam Action III which had been prevented by the security forces (police). Some media informed that those santris on foot were unable to depart by public transportation because their departure was prevented by the security forces and hence decided to 'walk'. This action emerged emotional reaction and developed sympathetic sentiments from a variety of Muslim circles in particular and immediately organized support to provide'logistics' for those santris. This narration, which initially came from social media then be broadcasted continually in the mainstream media,emerges larger emotional sentiment, so the support for the Defending Islam Action III (212) was even greater.

This action is claimed to be the largest Muslim mass movement in Indonesia in this century carried out peacefully and in an orderly manner because it was attended by millions of people from all over Indonesia. Those who are involved in and attend to this movement also claim that their voluntary and massive arrival of the capital voiced one thing, namely justice for Muslims and Islam. However, in the midst of the protesters in Jakarta, the action did not receive official support from the two main Islamic organizations in Indonesia; Muhammadiyah and Nahdhatul Ulama. These two mainstream Islamic organizations seem to have lost their authority as institutions that shape Muslim religious attitudes and actions during the Ahok case in Indonesia.

In fact, Rizieq Syihab and his supporters were able to make good use of this momentum to gain much support from community involvement and proclaimed himself not only to be the High Priest (Imam Besar) of the Front Pembela Islam (FPI/ Islam Defender Front) but also as the High Priest of the Indonesian Muslim Community in general. FPI sent the bai'at (loyalty pledge) to various individuals and pesantrens. It contained the willingness and faithful promise "to appoint Dr. Habib Muhammad Rizieq Syihab, Lc, MA, DPMSS, as the High Priest of Indonesian Muslims and pledge allegiance to his commands and prohibitions in accordance with the shari'a of Allah SWT and His Prophet." Some people see this as joke and ridicule, but some have accepted this invitation openly and take it as something serious.

Of course, this shifting religious authority has its main support from the massive use of social media. Social media, in this case, is able to change the pattern of society in gaining religious knowledge, a place to ask questions about religious issues, and figures that they make role models in religious life. In the traditional pattern, religious leaders or traditional religious authority refer to those who have strictly and long-term studied in pesantren, Islamic universities, or any other Islamic institutions.Hence, with such a background they have the capacity to convey religious messages and recognized by the community. They are ulama, kyai, murshid, and religious teachers. But now, supported by the factors of the role of social media and interventions in the era of disruption, religious authority is shifted to a new religious authority through impersonal media, such as websites, blogs, Instagram, Youtube and the like. Everyone can easily access knowledge according to their individual tastes and needs.

\section{Conclusion}

The existence of Islamic Persuasive Messages (IPM) that spread massively in the public sphere since the collapse of the New Order, especially in the form of memes, posters, banners, and viral-broadcasts on social media, is a precedent for the process of establishing new meanings of the Muslim piety that takes place continuously and in quite a long time. The spread of Islamic persuasive messages then gave birth to trends of piety in public spaces, both in fashion, lifestyle, communication ways, until the choice of residential or property. Of course, this change in trend also invites religious discourse in the public domain, especially in the process of 
interpreting "Islamic identity". Some of them criticize some existing local religious traditions and sometimes deem them as bid'aor un-Islamic practices, but some consider them as cultural expressions of Islamic teachings. The debate over religious discourse has intensified when the spread of transnational religious understanding has spread to many parts of Indonesia, especially when they are mostly people who are active in social media.

This phenomena shows that people have their own political and emotional choices that are supported by opportunities to access information and sometimes the choices are different from the minds of the traditional ulama. Therefore, the map of Islam in Indonesia can no longer be reduced or represented by two large Muslim organizations, Muhammadiyah and Nahdlatul Ulama. There are other Islamic colors, as represented by FPI and transnational Islamic organizations that continue to grow and challenge the existence of the two oldest and largest mass organizations.

\section{Referensces}

[1] A. Azra, "Political Islam in Post-Soeharto Indonesia," in Islamic Perspectives on the New Millenium, V. Hooker and A. Saikal, Eds. Singapore: ISEAS, 2004, pp. 133-149.

[2] N. Hasan, The Making of Public Islam Piety, Democracy and Youth in Indonesian Politics. Yogyakarta: SUKA Press, 2013.

[3] N. Hasan and I. Abubakar, Eds., Islam di Ruang Publik: Politik Identitas dan Masa Depan Demokrasi di Indonesia. Jakarta: CSRC dan UIN Jakarta, 2011.

[4] A. S. Pamungkas and G. Oktaviani, "Aksi Bela Islam dan Ruang Publik Muslim: Dari Representasi Daring ke Komunitas Luring," J. Pemikir. Sosiol., vol. 4, no. 2, pp. 65-87.

[5] M. Ahyar and Alfitri, "Aksi Bela Islam: Islamic Clicktivism and the New Authority of Religious Propaganda in the Millennial Age in Indonesia," Indones. J. Islam Muslim Soc., vol. 9, no. 1, pp. 1-29, 2019.

[6] R. W. Hafner, Civil Islam, Muslim and Democratization in Indonesia. Princeton: Princeton University Press, 2000.

[7] R. Lukens-bull, A Peaceful Jihad: Negotiating Identity and Modernity in Muslim Java. New York: Palgrave MacMillan, 2005.

[8] A. Salvatore and D. Eickelman, "Public Islam and the Common Good," in Public Islam and the Common Good, A. Salvatore and D. Eickelman, Eds. Leiden: Brill, 2004, pp. xi-xxv.

[9] A. N. Burhani, “Aksi Bela Islam: Konservatisme dan Fragmentasi Otoritas Keagamaan,” Maarif, vol. 11, no. 2, pp. 15-29, 2016.

[10] A. G. Herdiansah, D. A. Putri, L. Ashari, and R. Maduratmi, "The Islam Defence Action: A Challenge of Islamic Movement to Democratic Transition in the Post 2014 Indonesia," Wacana, vol. 20, no. 2, pp. 57-67, 2017.

[11] A. Heryanto, Identitas dan Kenikmatan: Politik Budaya Layar Indonesia. Jakarta: KPG (Kepustakaan Populer Gramedia), 2015.

[12] Datareportal, "Digital 2019: Indonesia - DataReportal - Global Digital Insights," 31 January, 2019. .

[13] P. Hopkins, M.-P. Kwan, and C. Aitchison, Geographies of Muslim identities: diaspora, gender and belonging, vol. 99, no. 3. 2006.

[14] N. Kirmani, "Competing Constructions of 'Muslim-ness' in the South Delhi Neighborhood of Zakir Nagar," J. Muslim Minor. Aff., vol. 28, no. 3, pp. 355-370, 2008.

[15] J. Rumi, "Shifting the Boundaries: Revisiting Islam and Muslimness," Third Fram., vol. 2, no. 2, 2009.

\section{Websites and Interviews}

http://onedayonejuz.org/post/detail/21/apa-itu-onedayonejuz-?\#.VtkwdFR97IV

“'Ngaji” 2 juz, Boleh Makan Gratis di Warteg Joni Abadi” in
http://regional.kompas.com/read/2016/01/29/08562311/.Ngaji.2.Juz.Boleh.Makan.Gratis.di.Warteg.Joni.
Abadi. Accessed March, 4, 2016
http://pemudahijrah.com/


Interview with Rahma (female, 24 years old) in Serang, Banten, on 22 July 2019

Interview with Zahra (female, 26 years old) in Serang, Banten, on 22 July 2019

Interview with Firda (female, 19 years old) in South Jakarta on 5 August 2019

Interview with Ummu Salamah (female, 28 years old) in South Jakarta on 5 August 2019

Interview with Hafid (male, 29 years old) in Serang, Banten, on 29 July 2019

Interview with Marwan (male, 25 years old) in Serang, Banten, on 29 July 2019 